\title{
THE SUB-CHRONIC TOXICITY TEST OF MENIRAN (Phyllanthus niruri L.) AND PEGAGAN (Centella asiatica) EXTRACT IN WISTAR STRAIN RATS ON LIVER AND KIDNEY FUNCTION
}

\author{
Endang Darmawan*), lin Narwanti, Siti Fatmawati Fatimah, \\ Ira Aprilia Wulandari, Ria Putri Salma, Dzulhaifa
}

Faculty of Pharmacy, Ahmad Dahlan University, Jln. Prof. Dr. Soepomo, 55164, Yogyakarta, Indonesia

Received August 10, 2019; Accepted November 21, 2019

\begin{abstract}
Meniran (Phyllantus niruri L.) and Pegagan (Centella asiatica L.) was proven had activity that considered as an antioxidant. However, the safety was not confirmed. This research is intended to evaluate sub-chronic toxicity of standardized combination extract of meniran and pegagan on liver and kidney function. This research used post-test-control design. Twenty female and twenty male Wistar strain rats divided into 4 groups. The first group was controlled in dosage of CMC Na $0.5 \%$. The others were given a combination of meniran and pegagan extract in ratio with different dosage (50:50;250:250; and 1250:1250 $\mathrm{mg} / \mathrm{KgBW}$ ). Sub-chronic toxicity test of meniran and pegagan combination was given orally once a day for 28 consecutive days. On the 29th day, all the rats were sacrificed and blood samples were analyzed using automatic analyzer. SGOT, SGPT, BUN, and creatinine value were statistically analyzed using one way ANOVA with post hoc LSD $(\mathrm{p}<0.05)$. The results show that treatment of meniran and gotu kola combination had no significantly different of SGOT and creatinine value of male and female rats, and SGPT value of male rats $(p>0.05)$. The treatment of meniran and gotu kola combination had significantly different of BUN value of male and female rats, and SGPT value of female rats $(p<0.05)$ but still within normal range. Based on this study, it can be concluded that orally administered of meniran and gotu kola extract combination at doses 50:50 $\mathrm{mg} / \mathrm{KgBW} ; 250: 250 \mathrm{mg} / \mathrm{KgBW}$; and $1250: 1250 \mathrm{mg} / \mathrm{KgBW}$ had no affected on SGOT, SGPT, BUN and creatinine value of Wistar strain rats on sub-chronic administration for 28 consecutive days.
\end{abstract}

Keywords: Phyllantus niruri L.; Centella asiatica L.; subchronic toxicity; liver and kidney function

\section{INTRODUCTION}

Meniran (Phyllantus niruri L.) and Pegagan (Centella asiatica L.) are the most found plants in Indonesia as herbal or traditional cure. Pegagan has substances, comprising of triterpenoid saponin, flavonoid, essential oil, phytosterol and other active materials (Kristanti, 2010). Additionally, Meniran has many advantages derived from substances of various chemical substances, such as alkaloid (securinine),

flavonoid (quercetin, quercitrin,
isoquercitrin, astragalin, niruri, rutine, leucodelphinidin, and galocatecine), and lignan (filantine and hipofilantine) (Mangunwardoyo et al., 2009).

Utilization of both plants as traditional cure require further research to prove feasibility and security. A study of Fitrianingsih (2017) postulated that combination of meniran and celery at dosage of 100:50 $\mathrm{mg} / \mathrm{KgBW}$ can decrease significantly the extent of blood urea nitrogen (BUN) $(p>0,05)$, while, at 
dosage of 100:100 and 50:100 $\mathrm{mg} / \mathrm{KgBW}$, it has not decreased the level of BUN and creatinine of rats induced by gentamycin significantly $(p>0,05)$. Other researches stated that there are components of meniran and pegagan having adverse effects on body's organ. Research performed by Praptiwi (2010) argued that saponin substance is main component of pegagan extract that can cause hemolysis and decrease surface pressure, so that it can result degeneration and sinusoid congestion, color changing and there is white spot in liver caused by cell destruction and leucocyte accumulation. Further, a study done by Mulyadi (2010) set forth that tannin substance in meniran can provide worse depiction of histopathology against mice's gastric and duodenum at dosage administer up to $2.000 \mathrm{mg} / \mathrm{kgBW}$. Anfiandi (2013) then reported that infuse of pegagan leaves at dosage of 1.500 $\mathrm{mg} / \mathrm{kgBW}$ can provide teratogenic effect against mice, such as physical defect, stunting, and hemorrhagic on mice's fetus. Therefore, it is necessary to design a test to acknowledge security from utilization of meniran and pegagan extract combination.

Sub-chronic toxicity testing of meniran extract at dosage of 2.000 $\mathrm{mg} / \mathrm{KgBW}$ and $5.000 \mathrm{mg} / \mathrm{KgBW}$ showed that there is no significant difference against the content of serum glutamic oxaloacetic transaminase (SGOT) and serum glutamic pyruvic transaminase (SGPT) of rats after 14 days of administering (Asare et al., 2011). While, Sujono et al. (2015) stated that administering of ethanol-meniran extract at dosage of $50 \mathrm{mg} / \mathrm{KgBW}$ and 250 $\mathrm{mg} / \mathrm{KgBW}$ does not cause significant difference against decreasing SGPT level measured in the 0-day and 90-day at Sprague Dawley strain rats. Another research depicted that repeated dosage of pegagan extract at $9.07 \mathrm{mg} / 20$ grams to mice or equivalent to $63.49 \mathrm{mg} / 200$ grams of rats can cause changes of liver and kidney (Praptiwi, 2010).

Based on above description, this research is significantly to be performed aimed to analyze sub-chronic toxicity against liver and kidney function from both meniran and pegagan extract combination since both extracts have activity as anti-oxidant.

\section{METHOD}

\section{Materials and Tools}

Materials employed in this research were standardized dried meniran extract (number of bets 049PP02.2) and nonspecifically standardized dried pegagan (number of bets 056PP01.2) obtained from PT. Industri Jamu Borobudur, sodium carboxymethil cellulose (CMC $\mathrm{Na}$ and aquadest derived from Laboratory of Pharmaceutical Technic of Ahmad Dahlan University, reagent tube obtained from Laboratory of Parahita, and male and female Wistar strain rats aged 2-3 moths and weighted 100-300 grams obtained from Integrated Testing and Research Laboratory, Universitas Gadjah Mada, Yogyakarta.

In addition, tools used was measuring glass (Pyrex, Indonesia), volumetric flask (Iwaki, Indonesia), measuring pipette (Iwaki, Indonesia), beaker glass (Pyrex, Indonesia), spatula, orally injection needle, 5-cc syringe, analytic weight (Sartorius, Indonesia), electric stove, a series of surgery tools (nippers, scalpel, blade, scissor), flacon, vacutainer tube, and automatic analyzer (Sysmex XT-2000i).

\section{Method}

\section{Designing 0.5 \% of CMC Na}

CMC Na with concentration $0.5 \%$ was used to suspense dried meniran and pegagan extract. The manufacturing, $0.5 \%$ of $\mathrm{CMC} \mathrm{Na}$, was by weighting $0.5 \%$ of $\mathrm{CMC} \mathrm{Na}$ as 0.5 grams and solved it little by little into $100,0 \mathrm{~mL}$ of heated aquadest. Such mixing was then 
homogenously stirred until colorless liquid was obtained. Further, 0.5\% solution of CMC Na utilized to suspense dried extract was always made freshly every time it would be used.

\section{Designing of Meniran and Pegagan Suspension Extract}

The design of suspension extract was always made freshly as it would be administered to test rats for each group. It was made from stock solution by concentration of $25 \% \mathrm{~b} / \mathrm{v}$. At dosage of $1250 \mathrm{mg} / \mathrm{kgBW}$, it was made by weighing each extract of 12.5 grams. Next, it was suspended with $0.5 \%$ of $\mathrm{CMC} \mathrm{Na}$ and $50.0 \mathrm{~mL}$ of ad, so that $25 \%$ $\mathrm{b} / \mathrm{v}$ of concentration was obtained. Further, this design of suspension at dosage of $250 \mathrm{mg} / \mathrm{kgBW}$ and 50 $\mathrm{mg} / \mathrm{kgBW}$ used following formulation:

$\mathrm{V}_{1} \mathrm{M}_{1}=\mathrm{V}_{2} \mathrm{M}_{2}$

Solution at dosage of $50 \mathrm{mg} / \mathrm{kgBW}$ was made by taking $1,0 \mathrm{~mL}$ of suspension stock and $25,0 \mathrm{~mL}$ of ad using $0,5 \%$ of CMC Na, so that $1 \% \mathrm{~b} / \mathrm{v}$ of concentration was obtained. The design of suspension at dosage of $250 \mathrm{mg} / \mathrm{kgBW}$ was made by taking $5,0 \mathrm{~mL}$ of suspension stock and $25,0 \mathrm{~mL}$ of ad, using $0,5 \%$ of $\mathrm{CMC} \mathrm{Na}$, so that $5 \% \mathrm{~b} / \mathrm{v}$ of concentration was obtained. As an example of calculation for dosage administered to every 200 grams of rat at dosage of $50 \mathrm{mg} / \mathrm{KgBW}$, it can be seen in following equation:

$\frac{\text { Dosage of extract }(\mathrm{mg})}{1000 \mathrm{grams}}=\frac{\text { Dosage given }}{200 \text { grams }}$
$\frac{50 \mathrm{mg}}{1000 \mathrm{grams}}=\frac{\text { Dosage given }}{200 \text { grams }}$

Dosage given $=5 \mathrm{mg}$

As an example of calculation for administering volume for every 200 grams of rat at dosage of $50 \mathrm{mg} / \mathrm{KgBW}$, it can be seen in following equation:

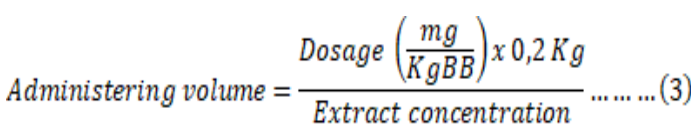

Administering volume $=\frac{50 \frac{m g}{K g B B} \times 0,2 K g}{1 \% b / v}$

Administering volume $=\frac{50 \frac{\mathrm{mg}}{\mathrm{KgBB}} \times 0,2 \mathrm{Kg}}{10 \mathrm{mg} / \mathrm{mL}}$

Administering volume $=1 \mathrm{~mL}$

\section{Treatment of Test Rats}

The research was performed in the Laboratory of Faculty of Pharmacy, Ahmad Dahlan University, Yogyakarta. Administratively, this procedure had obtained letter of statement of Committee of Research Ethics, Ahmad Dahlan University under No. 011803043. This study, then, was according to Regulation of Head of Food and Drug Supervisory of the Republic of Indonesia Number 7 of 2014 on Manual of Non-Clinical Toxicity Test by In Vivo (Anonim, 2014). Wistar strain rats thus were selected randomly, and 5 rats were classified into male and female group, respectively. Test rats were previously adapted for 1 week prior to treatment process. Treatment of each test group can be seen in following Table I.

Table I. Treatment of Test Rats

\begin{tabular}{ccl}
\hline No. & Group & \multicolumn{1}{c}{ Description } \\
\hline 1. & Group & $\begin{array}{l}\text { Administered feed + drink and } \\
\text { suspension of 0,5\% of CMC Na }\end{array}$ \\
\hline 2. & Group & $\begin{array}{l}\text { Administered feed + drink and } \\
\text { extract combination of meniran } \\
\text { and pegagan at dosage of 50:50 } \\
\text { mg/kgBW }\end{array}$ \\
3. & III & $\begin{array}{l}\text { feed }+ \text { drink and extract } \\
\text { combination of meniran and } \\
\text { pegagan at dosage of 250:250 } \\
\text { mg/kgBW }\end{array}$ \\
\hline feed + drink and extract \\
4. & Group & $\begin{array}{l}\text { combination of meniran and } \\
\text { pegagan at dosage of 1250:1250 } \\
\text { mg/kgBW }\end{array}$ \\
& IV
\end{tabular}




\section{Clinically Bio-chemical Test}

At the $29^{\text {th }}$ day, sampling through sinus orbitalis was performed, which the blood was contained into vacutainer tube. It then was tested in the Laboratory of Parahita to know the value of SGOT, SGPT, BUN, and creatinine.

\section{Data Analysis}

The result of this research gained data comprising of the level of SGOT, SGPT, BUN, and creatinine for each group, respectively. Such data was statistically analyzed. Data analysis of clinically biochemical parameter employed SPSS (statistic product and service solutions). The first analysis was distribution test using the Shapiro Wilk test to examine data distribution, and the Levene test was aimed to see data homogeneity. If data was normally and homogenously distributed, parametrically statistical test of one-way ANOVA was done using SPSS by reliable degree of $95 \%$ to acknowledge which group showed difference.

\section{RESULT AND DISCUSSION}

This study is aimed to know subchronic toxicity of meniran and pegagan extract combination against liver and kidney function during 28 days of orally administering with various dosage levels. It utilized test rats of male and female Wistar strain as many as 40 rats.

SGPT was mostly found in liver, so that SGPT was more specific to detect disease than SGOT. The measurement result of SGPT for male and female can be seen in following Figure 1, and for female, it can be viewed from Figure 2 .

According to Figure 1, the analysis result of one-way ANOVA depicts that there was no significant difference toward SGPT value of male rats, showed by its significant value of $0,105(p>0,05)$. Average value of SGPT from male rats in controlled group was $90.96 \pm 24.22 \mathrm{U} / \mathrm{L}$. The SGPT had consecutive decreasing value than controlling group did. The higher dosage of meniran and pegagan extract combination, the more decreasing the SGPT level of test rats. Based on such result, the extract combination of meniran and pegagan could prevent the increasing value of SGPT on male rats. It is probably because meniran and pegagan contain polyphenol and triterpenoid, having activity as antioxidant, so that it can decrease enzyme level produced by liver, as cell necrosis takes place (Hashim et al., 2011; $\mathrm{Hu}, 2011)$.

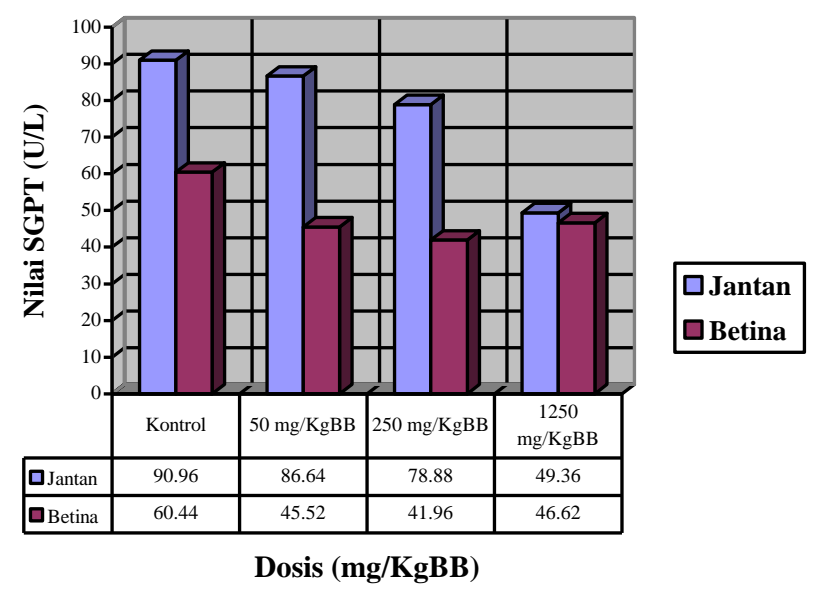

Figure 1. The average SGPT value of male and female rats after the administration of a combination of Meniran and Gotu kola extract for 28 days 
Meanwhile, the analysis result of one-way ANOVA in the Figure 1 shows that there was no significant difference in the SGPT value of female rats, depicted by its significant value of $0,059(p>0,05)$. Average SGPT value of female rats in the controlled group was $60.44 \pm 15.45 \mathrm{U} / \mathrm{L}$. The SGPT value of each group administered extract combination was lower than controlling group. However, such decreasing was in normal level of rats' SGPT, which was 35.9-81.6 U/L (Wicaksono, 2010). Based on such result, extract combination of meniran and pegagan could prevent increasing value of SGPT on female rats. Further, the decreasing value of SGPT in treatment group under administering of meniran and pegagan extract combination could happen since meniran contains filantine, having activity as antioxidant, so that it can protect liver from cell degeneration or impairment.

In detail, based on Figure 1, the SGPT value of male group was higher than female group. This was caused by physiology factor of those test rats. While, statistical result demonstrates that there was no significant difference on decreasing value of SGPT on male and female rats $(p>0.05)$. Further, it can be said that administering of meniran and pegagan extract combination to male and female Wistar strain rats would not interfere the SGPT value.

Subsequently, SGOT is enzyme existed in body to promptly detect periphery circulation, if there is trauma or necrosis in certain tissue. Also, SGOT is greatly found in any tissue other than liver, such as heart. In general, changing level of SGOT is related to liver disease, but it is also possible that the SGOT changes also take place due to heart disease (Yuwono et al., 2016). The calculation result of SGOT for group of male rats is shown in Figure 2, while female rats is in Figure 2.

According to Figure 2, the analysis result of one-way ANOVA in the Figure 2 describes that there was no significant difference of the SGOT value of male rats, depicted by its significant value of $0.354(p>0,05)$. Averagely, the rate value of SGOT from female rats in controlled group was $173.76 \pm 34.87 \mathrm{U} / \mathrm{L}$. Moreover, the SGOT value derived from administering of extract combination at dosage of $250: 250 \mathrm{mg} / \mathrm{kgBW}$ was higher than controlling group, which was 180.48 \pm 16.85 U/L. Nonetheless, such increasing was insignificant. Liver impairment can be seen from three folds increasing of SGOT and SGPT parameter from normally upper range (Maria, 2014). Then, the result obtained from the measurement of male's SGOT level (Figure 2) is that increasing of SGOT level had not reached more than three folds of normally upper range, so, as consequence, it can be said that there was no impairment of liver.

In addition, the analysis result of one-way ANOVA in the Figure 2 depicts that there was significant difference at the SGOT value of female rats, shown by its significant value of $0,026(p<0,05)$. In average, the SGOT value of female rats under controlled group was $174.5 \pm 23.37$ U/L. The SGOT value in each group administered with extract combination was lower than controlling group, yet it was still under normal range (35.7-168 U/L) (Wicaksono, 2010). Additionally, significant difference existing between controlling group against group administered with meniran and pegagan extract at dosage of 1250:1250 $\mathrm{mg} / \mathrm{KgBW}$ was shown by its significant value of $0.003(p<0.05)$. 

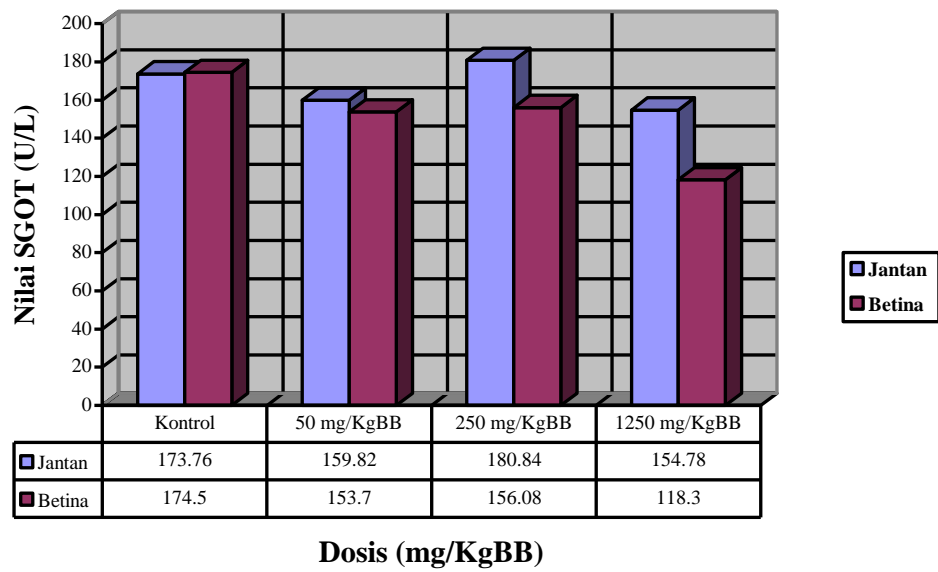

Betina

Figure 2. The average SGOT value of male and female rats after the administration of a combination of Meniran and Gotu kola extract for 28 days

Hence, according to such results, extract combination of meniran and pegagan could prevent increasing value of the SGOT at female rats. While, decreasing value of the SGOT was probably caused by polyphenol, contained in pegagan (Sutardi, 2016). Polyphenol has substance included in class of primary antioxidants, such as phenol substances enabling to cut off chain reaction of fatty-acid-free radical formation $(\mathrm{Hu}, 2011)$.

According to Figure 2, further, the SGOT value at male group was higher than female group was. It was probably caused that male rats had heavier muscle mass. Similarly, Tripathi and Hall (2016) argued that SGOT is mostly found in muscle, skeletal, heart, and brain. Therefore, the SGOT value of male rats is higher than female rats. Meanwhile, the statistical result demonstrates that there was no significant difference of the SGOT value found in male rats $(p=0.354)$. Contrastingly, the statistical result of the SGOT value found in female rats had significant difference against controlling group $(p=0.026)$. However, such decreasing was still in normal range, so that it can be concluded that administering of meniran and pegagan extract combination at male and female Wistar strain could not interfere the SGOT value.
Moreover, the level of BUN is final product from protein metabolism synthesized inside liver and secreted almost $75 \%$ through kidney without experiencing molecule changes. Increasing of BUN level in blood could show impairment of kidney function. The result of the BUN level derived from this research is then shown in following figures as attached.

Based on Figure 3, significant value from statistical test of one-way ANOVA was $0.025(p<0.05)$, meaning that there was significant difference. This result depicts that average value of BUN at $14.20 \pm 2.61$ was lower than controlling group $(0,5 \%$ of $\mathrm{CMC} \mathrm{Na})$, while the group III and IV demonstrated more significant increasing of BUN's average value than controlling group, which was $20.16 \pm 4.23$ and $19.00 \pm 1.97$, respectively, with increasing value of BUN where was still under normal range. In addition, normal value of BUN on mice was 13.9-28.3 mg/dL (Anshar, 2015). Based on above result, increasing value of BUN was necessarily cautioned since it could show impairment of kidney function (Haryoto et al., 2015). Main function of kidney is to regulate liquid and electrolyte balance and body's basal and acid to create figure environment for tissue and cell metabolism (Miriam and Wallace, 1998). 


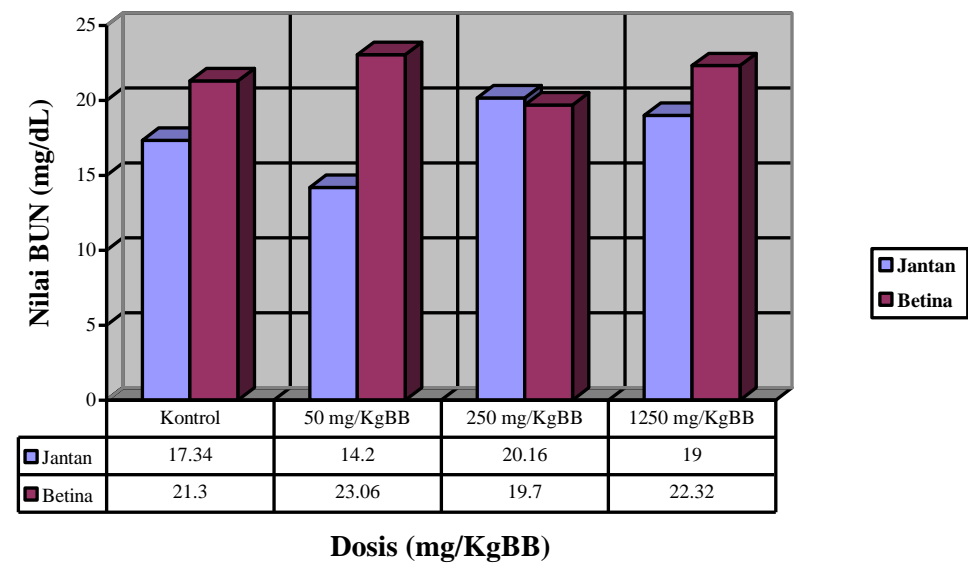

Figure 3. The average BUN value of male and female rats after the administration of a combination of Meniran and Gotu kola extract for 28 days

Figure 3 postulates that value of statistical for the BUN value on female rats was $0.031 \quad(p>0.05)$, meaning that there was significant difference. Thus, from Figure 3, it is known that group administered with meniran and pegagan at dosage of $250: 250 \mathrm{mg} / \mathrm{KgBW}$ showed decreasing value of the BUN as $19.70 \pm$ 0.52 rather than controlling group $(0.5 \%$ of $\mathrm{CMC} \mathrm{Na),} \mathrm{whereas} \mathrm{the} \mathrm{group} \mathrm{II} \mathrm{had}$ BUN value of $23.06 \pm 0.82$; and the group IV had $22.32 \pm 0.67$. Improvement of the BUN value was occurred on both groups than controlling group. Such increasing happened in the group II and IV of female rats, yet it was still in normal range.

Next, based on Figure 4, the analysis result of one-way ANOVA gained was significant value of 0,590 $(p>0.05)$. It means that there was no significant difference. Such result shows that there was increasing of creatinine value of three groups than controlling group $(0.5 \%$ of $\mathrm{CMC} \mathrm{Na})$. The group II demonstrated creatinine's average value of $0.56 \pm 0.07$; the group III was 0.52 \pm 0.09 ; and the group IV was $0.56 \pm 0.08$. Creatinine's reference value of Wistar rats was $0.2-0.8 \mathrm{mg} / \mathrm{dL}$ and it was secured due to below normal range (Amir et al., 2015).
Improvement of creatinine serum became impairment index and kidney disfunction. Kidney ability to filter nonprotein nitrogen (NPN) (metabolism product of phosphate creatinine) is lessen during kidney disfunction. It was due to declining glomerulus filtration (Reddy et al., 2012).

Lastly, based on Figure 4, it postulates that significance value of statistical test with one-way ANOVA as $0,181$ ( $p>0.05)$. It means that there was no significant difference. Moreover, the result depicts that the group II was more improving than controlling group $(0.5 \%$

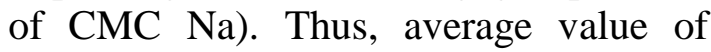
creatinine at the group II was $0.61 \pm 0.08$, while the controlling group was $0.56 \pm$ 0.09 . The average value of creatinine at the group III was $0.51 \pm 0.03$, and the group IV was $0.56 \pm 0.06$. Hence, there was decreasing occurred in the group III and IV, yet it was insignificant. 


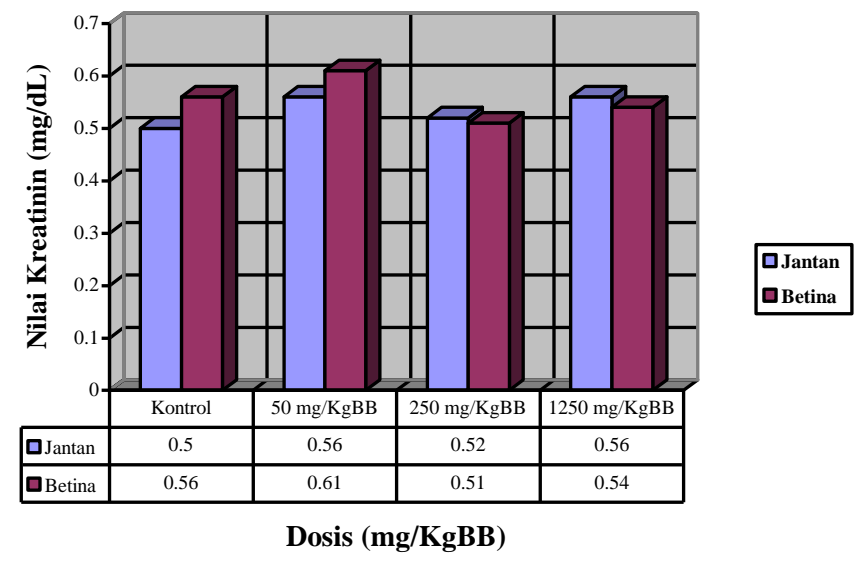

Figure 4. The average creatinine values of male and female rats after administration of a combination of Meniran and Gotu kola extract for 28 days

Any impairment of kidney function in determining minor, moderate, or major severity could be known from total value of glomerulus filtration (GFR) (Hutagaol, 2017). Also, other supporting impairment of kidney, such as kidney histopathology, usually depicted inflammation or focally lymphocyte cells infiltration and bleeding (Winarno and Sundari, 2011).

From above research's findings, administering of meniran and pegagan extract combination had not result adverse effect to liver and kidney function as seen in the level parameter of SGOT, SGPT, BUN, and creatinine, so it was secured and did not cause toxicity.

\section{CONCLUSION}

In sum up, according to research's findings, it can be concluded that orally administering of meniran and pegagan extract combination at dosage of 50:50; 250:250; and 1250:1250 $\mathrm{mg} / \mathrm{KgBW}$ had not affected SGOT, SGPT, BUN, and creatinine value in Wistar strain rats after sub-chronic toxicity test, administered for 28 days.

It is further necessary to perform histopathology to acknowledge liver and kidney in detail and research using more variative dosages in meniran and pegagan extract combination.

\section{ACKNOWLEDGEMENT}

The writers would like to thank to Research and Development Unit of Ahmad Dahlan University for funding under Competitive Grant Research.

\section{REFERENCES}

Amir, N., Suprayitno, E., Hardoko, dan Nursyam, H. 2015. Pengaruh Sipermetrin Pada Jambal Roti Terhadap Kadar Ureum Dan Kreatinin Tikus Wistar (Rattus norvegicus). Jurnal IPTEKS PSP. 2 (3), 283-293.

Anfiandi, V., 2013, Uji Teratogenik Infusa Daun Pegagan (Centella asiatica L. Urban) pada Mencit Betina (Mus musculus), Jurnal Ilmiah Mahasiswa, Universitas Surabaya, 2(1).

Anonim, 2014, Pedoman Uji Toksisitas Nonklinik Secara In Vivo, Balai Pengawasan Obat dan Makanan (BPOM), Jakarta.

Anshar, A.R. 2015. Pengaruh Pemberian Jus Buah Alpukat Terhadap Gambaran Kadar Blood Urea Nitrogen (Bun) dan Serum Kreatinin pada Tikus Putih (Rattus Norvegicus) yang Diinduksi Meloxicam Dosis Toksik Tesis]. Fakultas Kedokteran Hewan. Universitas Hasannudin. 
Asare, G.A., Addo, P., Bugyei, K., Gyan B., Adjei, S., Otu-Nyarko, L. S., Wiredu, E.K., dan Nyarko, A., 2011, Acute Toxicity Studies of Aqueous Leaf Extract of Phyllanthus niruri, Interdisciplinary Toxicology, (4).

Fitrianingsih, 2017, efek Nefrroprotektif Kombinasi Serbuk Ekstrak Meniran (Phyllanthus niruri L.) dan seledri (Apium graveolus L.) dengan Parameter Kadar BUN dan Kreatinin pada Tikus diinduksi Gentamisin, Skripsi, Universitas Ahmad Dahlan, Yogyakarta

Haryoto, Suhendi, Andi, Eka Prasnaparamita W., and Tanti Azizah Sujono, M., 2015, Uji Toksisitas Subkronik Ekstrak Etanol Daun Tumbuhan Sala (Cynometra ramiflora Linn.) dengan Parameter Kimia Urin dan Histopatologi Organ Ginjal pada Tikus Galur Wistar. The 2nd University Research Coloquium.

Hashim, P., Sidek, H., Helan, M.H.M., Sabery, A., Palanisamy, U.D., Ilham, M., 2011, Triterpene Composition and Bioactivities of Centella asiatica, Molecules, 16.

Hu, M.L., 2011, Dietary Polyphenol as Antioxidants and Anticancer Agents: More Questions than Answer, Journal of Food Science and Bioechnology. (9).

Hutagaol, E. V., 2017, Peningkatan Kualitas Hidup Pada Penderita Gagal Ginjal Kronik Yang Menjalani Terapi Hemodialisa Melalui Psychological Intervention Di Unit Hemodialisa Rs Royal Prima Medan Tahun 2016. Jurnal Universitas Prima Indonesia Meda, 2, 18.

Kristanti, A., 2010, Potensi Ekstrak Daun Pegagan (Centella asiatica (L.) Urban) Dosis Tinggi sebagai Antifertilitas pada Mencit (Mus musculus) Betina, Skripsi, Fakultas SAINS dan Teknologi Universitas Islam Negeri Maulana Malik Ibrahim, Malang.war Mangunwardoyo, W., Cahyaningsih, E., and Usia, Tepy., 2009, Ekstraksi dan Identifikasi Senyawa Antimikroba Herba Meniran (Phyllanthus niruri L.), Jurnal Ilmu Kefarmasian Indonesia, 7(2): 57-63

Miriam A., and Wallace, KN., 1998, Anatomy and Physiology of the Kidney, AORN Journal independent study, hal. 804.

Mulyadi, 2010, Uji Toksisitas Akut Ekstrak Meniran (Phyllantus niruri Linn) terhadap Gastrointestinal Mencit BALB/C, Skripsi, Fakultas Kedokteran Universitas Diponegor, Semarang Praptiwi, 2010, Efek Toksisitas Ekstrak Pegagan (Centella asiatica Linn.) pada Organ dan Jaringan Mencit (Mus musculus), Majalah Farmasi Indonesia, 21(1).

Reddy, V. C., Amulya, V., Lakshmi, C. A., Reddy, D. B. P. K., Pratima, D., Thirupathi, A. T., Sengottuvelu, S., 2012, Effect of Simvastatin in Gentamicin Induced Nephrotoxicity in Albino Rats. Asian Journal of Pharmaceutical and Clinical Research, 5(1), 36-40.

Sujono, T. A., Wahyuni, S. A., Da'i, M., Kusumowati, I. T.D., Suhendi, A., Munawaroh, R., Pratiwi, N., Fauziyyah, S., Rahadini, R., Lestari S., 2015, Pengaruh Pemberian Ekstrak Etanol Meniran (Phyllanthus niruri L) selama 90 Hari terhadap Fungsi Hati Tikus, University Research Colloquium, Fakultas Farmasi Universitas Muhammadiyah Sukarta.

Sulistyoningrum, E., and Pribadi, F.W., 2010, Pengaruh Pemberian 
Suspensi Meniran (Phyllanthus niruri L.) Terhadap Kerusakan epar Tikus Putih Yang Diinduksi Antituberkulosis Rifampisin dan Isoniazid, Mandala of Health. Vol. 4 No 1.

Sutardi, 2016, Kandungan Bahan Aktif Tanaman Pegagan dan Khasiatnya untuk Meningkatkan Sistem Imun Tubuh, Jurnal Litbang Pertanian, 35(3).

Tripathi, N.K., dan Hall, R.L., 2016, Animal Models in Toxicology $3^{\text {rd }}$ Edition, CRC Press, Boca Raton.

Wicaksono, M.A., 2010, Evaluasi Fungsi Hati Dan Ginjal Tikus Betina (Rattus Norvegicus) Galur Sprague-Dawley Pada Pemberian Jamu Galohgor Dengan Dosis Bertingkat. Tesis. Institut Pertanian Bogor. Bogor

Winarno, W. M., dan Sundari, D., 2011, Uji Toksisitas Sub Kronik Ekstrak Daun Kembang Sungsang (Gloriosa superba L.) terhadap Fungsi Ginjal Tikus Putih. Pengembangan Biomedis Dan Farmasi Jakarta, 1, 186-191.

Yuwono, B., Sulistyani, E., Qodriyati, N.L.Y., 2016, Kadar Serum Glutamic Oxaloacetic Transaminase (SGOT) pada Tikus Wistar (Rattus norvegicus) Jantan yang Dipapar Stresor Rasa Sakit Electrical Foot Shock selama 28 Hari on Iurnal Pustalen 